There is no simple certain way of knowing whether the blood of an HBsAg carrier is infectious. The available evidence suggests that carriers in the health care professions are not sources of infection to their patients. ${ }^{13} 14$ It is unlikely therefore that these children are a source of infection to their classmates, but the lack of data on hepatitis in children indicates caution and a need for further studies.

Although we studied only a few families our results show that HBsAg can spread within the family. They also show how a reservoir of hepatitis $B$ infection can be maintained from one generation to the next, ${ }^{1 ;} 16$ even though, as is the case in Scotland the prevalence of $\mathrm{HBsAg}$ carriage and acute hepatitis B infection within the community may be comparatively low. The higher prevalence of $\mathrm{HBsAg}$ in immigrant children, and, by implication, in the immigrant community, suggests that the reservoir is being maintained at a higher level than was the case before mass immigration.

The low prevalence of tuberculin sensitivity in immigrant children in this survey $\left(1.25^{\circ}{ }_{0}\right)$ probably indicates a decline in tuberculosis in this group. This is possibly due to the fact that $72^{\circ}{ }_{0}$ of the immigrant children in this survey were born in the United Kingdom and $94^{\circ}{ }^{\circ}$, had had BCG vaccination irrespective of the country of origin. The notification rate among immigrant children in Glasgow is lower than that in the native-born group. From 1971 there were 98 notifications of both pulmonary and non-pulmonary tuberculosis in children. Only 12 cases were in immigrants. ${ }^{1-}$ The policy of taking chest radiographs of immigrants from countries where tuberculosis is prevalent at the port of entry and of giving BCG vaccination to children in their country of origin and in the United Kingdom has promoted this decline. Springett " reported that if exposure to tuberculosis before migration were an important factor in determining clinical infection after migration then it would be reasonable to expect that notification rates would be at their highest shortly after arrival and would decline with length of stay in this country. If this trend continues the immigrant children will soon be out of the high-risk group.

Immigrant children clearly do not constitute a major health hazard to the indigenous population. This is reassuring, especially as some members of all the Chinese and many of the Asian families in this survey worked as food handlers in restaurants or in grocery shops. We suggest, however, that a similar survey of children from various racial groups should be carried out in other parts of the United Kingdom so that the results could be compared.

We thank Miss Stella Reekie, social worker, Miss $\mathrm{K}$ Chung, secretary of the Chinese Christian Fellowship, and Miss B McGregor, Miss S Alpine, and Mrs E Sharp, health visitors, for organising the survey clinic. We would also like to thank $\mathrm{Mr}$ J Givan, $\mathrm{Mr} \mathrm{S} \mathrm{Mc}$ Michael, Mrs Ruth Gray, and Miss Ann Williamson for technical help.

Requests for reprints should be addressed to Dr K M Goel, Royal Hospital for Sick Children, Yorkhill, Glasgow G3 8SJ.

\section{References}

${ }^{1}$ Maegraith, B, Lancet, 1963, 1, 401.

Stroud, C E, Postgraduate Medical fournal, 1965, 41, 599

${ }^{3}$ Walters, J H, Postgraduate Medical fournal, 1965, 41, 584.

- Thompson, R G, Hutchison, J G P, and Johnston, N M, British Medical fournal, 1972, 1, 591 .

Springett, V H, British fournal of Preventive and Social Medicine, 1973, 27, 242 .

${ }^{6}$ Mackay-Dick, J, Lancet, 1974, 2, 108

' Goel, K M, et al, Lancet, 1976, 1, 1141.

${ }^{8}$ Cruickshank, R, Medical Microbiology, 11 th edn, p 548. Edinburgh and London, Livingstone, 1965.

${ }^{9}$ Stewart, S, Bigger's Handbook of Bacteriology, 8th edn, p 343. London, Bailliere, Tindall and Cox, 1962.

${ }_{10}$ Poole, P M, Postgraduate Medical fournal, 1975, 51, 433.

${ }^{11}$ Payne, R W, Barr, A, and Wallace, J, Fournal of Clinical Pathology, 1974, 27, 125

${ }^{12}$ World Health Organisation, Viral Hepatitis, Technical Report Series No 512, p 13. Geneva, WHO, 1973.

${ }^{13}$ Alter, H J, et al, New England fournal of Medicine, 1975, 292, 454.

14 Williams, S V, Pattison, C P, and Berguist, K R, fournal of the American Medical Association, 1975, 232, 1231.

${ }^{5}$ Reddy, T A, personal communication, 1976

${ }^{16}$ Szmuness, W, Harley, E J, and Prince, E M, American fournal of Medical Science, 1975, 270, 293.

17 Wilson, W D, personal communication, 1976.

(Accepted 31 December, 1976)

\title{
Somatomedin in growth disorders and chronic renal insufficiency in children
}

\author{
S L SCHWALBE, P R BETTS, P H W RAYNER, B T RUDD
}

British Medical fournal, 1977, 1, 679-682

\section{Summary}

Somatomedin activity was measured using an embryonic chick cartilage assay in 33 normal and short normal children, 23 children with pituitary growth hormone (GH) deficiency, 14 children with sexual precocity, and

\footnotetext{
Institute of Child Health, University of Birmingham, Birmingham B16 8ET

$S$ L SCHWALBE, PHD, research fellow

P R BETTS, MB, MRCP, lecturer in paediatrics and child health

P H W RAYNER, BSC, MRCP, senior lecturer in paediatrics and child health

Department of Clinical Endocrinology, Women's Hospital, Central Birmingham Healîh District

B T RUDD, PHD, principal biochemist
}

13 children with chronic renal insufficiency. In normal children somatomedin activity correlated well with chronological age: low values in early childhood rose to higher than adult levels at puberty. Children with GH deficiency had significantly lower activities and those with sexual precocity significantly higher activities than normal children. In all three groups somatomedin activity correlated well with bone age. In children with chronic renal insufficiency there was a significant correlation between decreasing somatomedin activity and both a reduced growth velocity and a falling glomerular filtration rate. Somatomedin activity and growth velocity were within normal limits in children with glomerular filtration rates above $30 \mathrm{ml} / \mathrm{min} / 1.73 \mathrm{~m}^{2}$.

\section{Introduction}

Salmon and Daughaday ${ }^{2}$ showed that growth hormone (GH) promoted skeletal growth by inducing a serum factor that 
stimulated the incorporation of radiolabelled sulphur into cartilage. This they called the sulphation factor. Subsequent studies have shown several other GH-dependent substances in serum which stimulate cellular events concerned with the growth of both skeletal and non-skeletal tissues-for example, the incorporation of thymidine into nucleic acid-and the broader term somatomedin was introduced. ${ }^{3}$ Most bioassay methods for somatomedin are based on incorporating ${ }^{35} \mathrm{~S}$ into cartilage. Salmon and Daughaday ${ }^{2}$ used costal cartilage from hypophysectomised rats in their assay, and others have used pelvic cartilage from chick embryos ${ }^{4}$ and pig costal cartilage. ${ }^{5}$

Since no organ has been identified that contains a higher concentration of somatomedin activity than native plasma, progress in isolating and characterising somatomedin has been slow. Three separate somatomedins-A, B, and C-have been isolated from acid ethanol extracts of large quantities of human plasma ${ }^{6}$ but no international reference preparation is available and the various bioassays in use may measure different somatomedins. The term somatomedin in this report indicates sulphation factor activity measured by the rate of uptake of radiolabelled sulphate into chick embryo cartilage. We determined somatomedin activity in normal and short normal children and compared the values with those in children with retarded growth due to pituitary GH deficiency and accelerated growth due to precocious sexual development.

Short stature is common in children with chronic renal insufficiency. After infancy these children usually grow satisfactorily until the glomerular filtration rate falls below $30 \mathrm{ml} /$ $\min / 1.73 \mathrm{~m}^{2}$, when a reduced growth velocity may occur.? Little information is available on the hormonal control of growth in children with chronic renal insufficiency. Somatomedin production can be shown from perfused kidney slices in vitro, ${ }^{8}$ although the physiological significance of this is unknown. Saenger et $^{a l^{9}}$ reported that somatomedin activity was low in children with severe renal insufficiency but rose after kidney transplantation. They did not, however, allow for changes in somatomedin activity with age, and all children were on prednisone treatment after transplantation, which is known to change somatomedin activity. ${ }^{10}$ To clarify these points we also investigated somatomedin activity in a group of children with varying degrees of chronic renal insufficiency.

\section{Patients and methods}

Four groups of children were studied. No sex difference in serum somatomedin activity was apparent in any group and the sexes were therefore analysed together.

Group 1 consisted of 33 normal and short normal children aged 1 to 16 years. No children showed evidence of hepatic, renal, or gastrointestinal disease. All short children had normal thyroid function and had radioimmunoassayable serum $\mathrm{GH}^{11}$ concentrations greater than $20 \mathrm{mU} / 1$ during a standardised insulin hypoglycaemia test $(0 \cdot 1 \mathrm{U}$ soluble insulin $/ \mathrm{kg}$ body weight $)$. All the children were assumed to have glomerular filtration rates above $70 \mathrm{ml} / \mathrm{min} / 1.73 \mathrm{~m}^{2}$.

Group 2 consisted of 23 children aged 5 to 19 years with pituitary GH deficiency. All children were less than 3.5 standard deviations below the mean height for their age, ${ }^{12}$ and bone age ${ }^{13}$ was retarded. Serum GH response to insulin hypoglycaemia was less than $10 \mathrm{mU} / 1$. Children with associated pituitary thyrotrophin deficiency were euthyroid on thyroxine replacement treatment at the time of study. None of the children had previously received human GH or cortisone.

Group 3 consisted of 14 sexually precocious children aged 2 to 8 years. The advanced pubertal development was due to either constitutional precocious puberty (11 cases) or congenital adrenal hyperplasia (21-hydroxylase deficiency) (three cases). All the children were tall for their age and had advanced bone ages. ${ }^{1: 3}$

Group 4 consisted of 13 children aged 5 to 17 years with chronic renal insufficiency. Glomerular filtration rates ranged from 5 to $31 \mathrm{ml} / \mathrm{min} / 1.73 \mathrm{~m}^{2}$ and were determined by creatinine clearance, ${ }^{14}$ or the slope clearance of ${ }^{51} \mathrm{Cr}$-labelled edetic acid ${ }^{15}$ in children with reflux nephropathy. None of the children were on any form of dietary restriction nor had they received peritoneal dialysis, haemodialysis, or steroids. Since all the children in this group had been followed for long periods growth velocity data were available for each of them.
Only one child was taller than the 50th centile for height and six were below the third centile. ${ }^{12}$

The method of assaying somatomedin was essentially that of Hall ${ }^{4}$ with modifications. Somatomedin activity was assayed using 11-dayold embryonic chick pelvic cartilage and radiolabelled $\left({ }^{35} \mathrm{~S}\right)$ sodium sulphate as an index of sulphate incorporation. The incubation medium contained benzylpenicillin $100 \mathrm{mmol} / \mathrm{l}(356 \mathrm{mg} / 100 \mathrm{ml})$ sodium salt $B P$ ) and streptomycin sulphate $B P 100 \mathrm{mg} / \mathrm{l}$ as used by Grant. ${ }^{16}$

Diluted serum was routinely heated at $56^{\circ} \mathrm{C}$ for 30 minutes to remove labile inhibitors. Cartilages were digested by the addition of $0.8 \mathrm{ml}$ Analar $90 \%$ formic acid and heating in a water bath at $100^{\circ} \mathrm{C}$ for 25 minutes. Liquid scintillation spectrometry was used to count the radioactivity in a triton-based scintillant. In all cases a symmetrical design was used with four cartilage leaflets at each of three dose levels $(5,10$, and $20 \% \mathrm{v} / \mathrm{v}$ serum). Assays were rejected as being invalid if the index of precision $(\lambda)$ exceeded 0.3 . In valid assays $\lambda$ ranged from $0 \cdot 11-0 \cdot 24$. Relative potencies, fiducial limits, and tests for parallelism and significant regression were computed by the method of Borth. ${ }^{17}$ Pooled serum from healthy men, with an assigned somatomedin activity of $1.0 \mathrm{unit} / \mathrm{ml}$, was used as reference standard.

All samples were taken between 0900 and 1000 , after an overnight fast. Serum was separated without delay and stored at $-20^{\circ} \mathrm{C}$ until assayed.

\section{Results}

Somatomedin activity correlated well with chronological age in the normal and short normal children $(\mathrm{r}=0.61 ; \mathrm{P}=<0.001$ ) (fig 1 ). Values were low in early childhood and exceeded adult values at puberty. The mean somatomedin activity for the group as a whole was $1 \cdot 08 \pm 0 \cdot 27$ units $/ \mathrm{ml}$.

Somatomedin levels at various ages were compared in groups 1,2 , and 3 (fig 2). In all groups somatomedin activity increased with age. In those aged under 6 the mean somatomedin activity of children in group $3(1.25 \pm 0.18 \mathrm{U} / \mathrm{ml})$ was significantly greater than that in children in group $1(0 \cdot 81 \pm 0 \cdot 15 \mathrm{U} / \mathrm{ml})$. In those aged $6-11$ years somatomedin activity in group $2(0 \cdot 76 \pm 0 \cdot 19 \mathrm{U} / \mathrm{ml})$ was significantly lower than that in group $1(1.06 \pm 0.15 \mathrm{U} / \mathrm{ml})$.

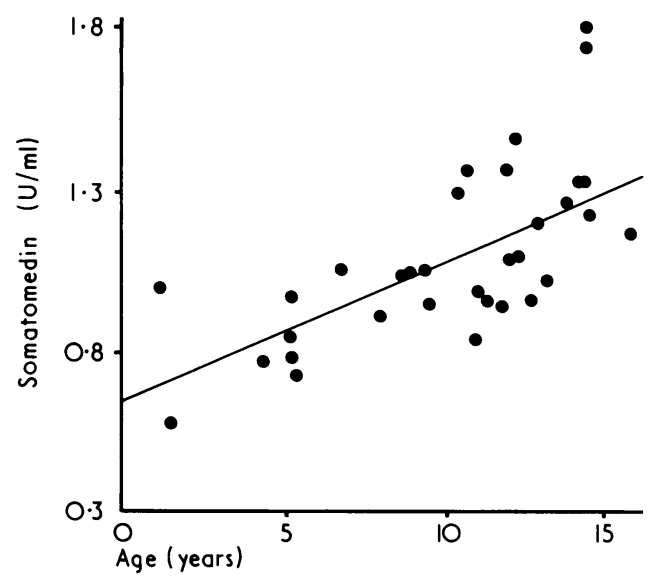

FIG 1-Relation of somatomedin activity to chronological age in normal and short normal children (group 1).

Assessment of skeletal maturation was available in 19 children in group 1,21 children in group 2, and 14 children in group 3 . When all three groups were considered together, somatomedin activity showed a highly significant correlation with bone age $(\mathrm{r}=0.53 ; \mathrm{P}=<0.001)$ (fig 3).

In group 4 the somatomedin activity in one child with chronic renal insufficiency could not be determined because inhibition occurred when increasing concentrations of sera were added to the media. Parallelism with the standard did not occur despite heating in an attempt to remove an inhibitor. The reason for this failure remains unknown. Somatomedin activity in each of the remaining 12 children with chronic renal insufficiency was below the mean for the control 


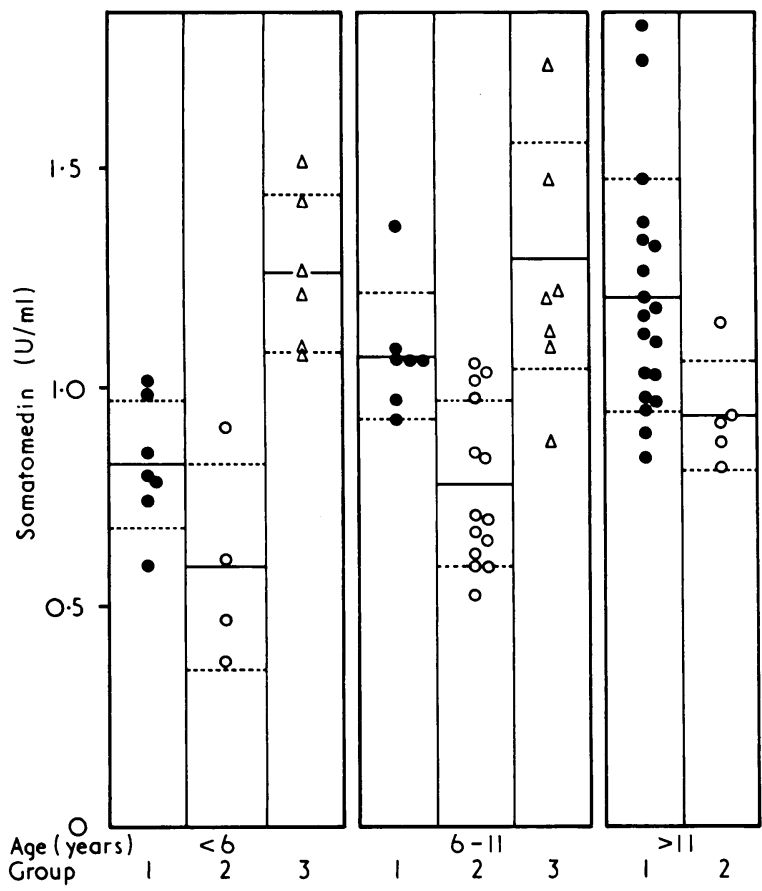

FIG 2 -Somatomedin activity in groups $1(0), 2(0)$, and $3(\triangle)$ according to age. Horizontal solid and dotted lines represent means \pm 1 standard deviation.

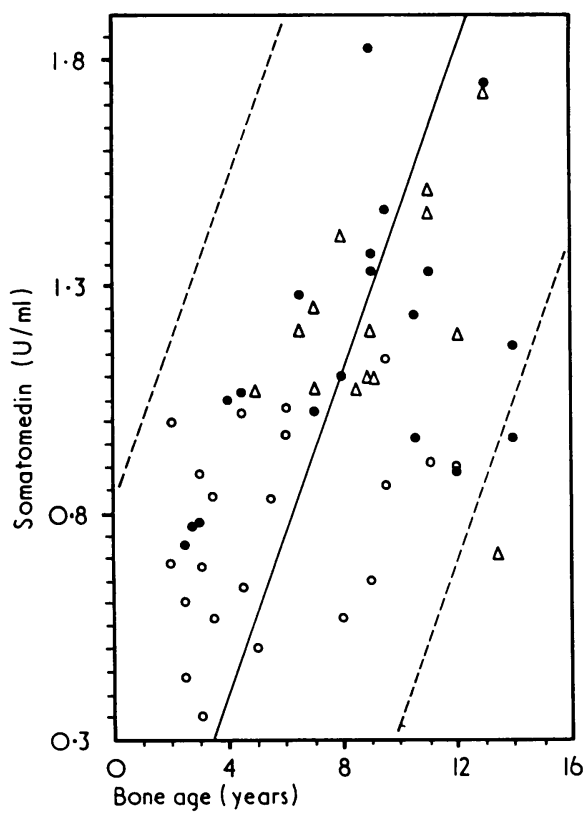

FIG 3-Relation between bone age and somatomedin activity in group $1(0)$, group $2(0)$, and group $3(\triangle)$.

children at each age. When this activity was expressed as a percentage of that expected for bone age (fig 4) there was a highly significant relation with growth velocity $(r=0.8 ; P=<0.01)$. Somatomedin activity was also significantly correlated with glomerular filtration rate (fig 5), activity decreasing with a reduction in glomerular filtration $(r=0.65 ; P=<0.05)$. From the regression line it can be seen that somatomedin activity was within the normal range when glomerular filtration rates were above $30 \mathrm{ml} / \mathrm{min} / 1.73 \mathrm{~m}^{2}$.

Since the method used for determining somatomedin activity depends on the radioactive uptake of sulphate into cartilage, we calculated the sulphate concentration of the media with the addition of varying amounts of sera. Normal plasma sulphate concentrations in children are reported to be $366 \pm(\mathrm{SD}) 63 \mathrm{nmol} / \mathrm{ml} .{ }^{18}$ Using these -values, and knowing that the sulphate concentration of the media before plasma was added was $1102 \mathrm{nmol} / \mathrm{ml}$, we calculated that the sulphate concentration after the addition of increasing amounts of serum from normal patients at $5 \%, 10 \%$, and $20 \%$ dilutions could range from $1065 \mathrm{nmol} / \mathrm{ml}$ to $955 \mathrm{nmol} / \mathrm{ml}$. The addition of increasing amounts of serum effectively diluted the sulphate concentration in the media. Sulphate concentrations in children with terminal renal failure may reach $2100 \mathrm{nmol} / \mathrm{ml}^{18}$ Therefore in those children with the severest degree of renal failure the maximum sulphate concentrations that may occur could similarly vary from 1150 to $1300 \mathrm{nmol} / \mathrm{ml}$ with the addition of increasing amounts of serum. Thus while there was little difference in sulphate concentrations after the addition of $5 \%$ plasma $(v / v)$ there was a possibility in those children with terminal renal failure of a $30^{\circ}$ o difference in sulphate concentration at the higher serum dilutions.

\section{Discussion}

After Salmon and Daughaday described sulphation factor activity ${ }^{12}$ it was widely used as an indirect assay of serum GH in pituitary dysfunction and growth disorders. The subsequent development of a radioimmunoassay ${ }^{19}$ for $\mathrm{GH}$ led to a decline in interest in somatomedin determinations, especially as radioimmunoassay proved much more reliable and reproducible for routine laboratory use. The physiological pattern of pituitary

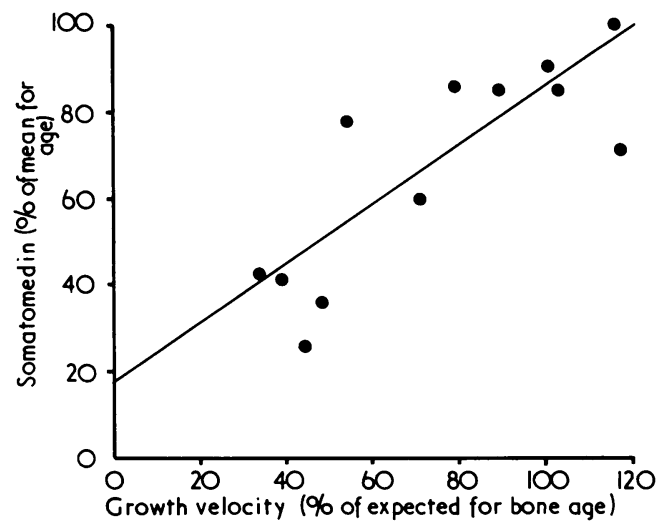

FIG 4-Relation between somatomedin activity and growth velocity, expressed as percentage of that expected for bone age in children with chronic renal insufficiency.

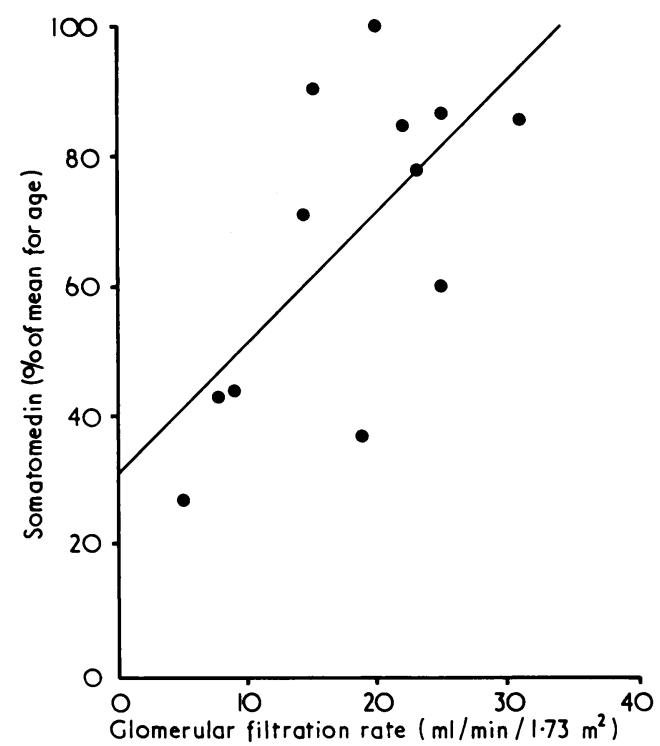

FIG 5-Relation between somatomedin activity and glomerular filtration rate. 
GH secretion, with low or absent levels during much of the day and short peaks of secretion occurring during sleep, ${ }^{20}$ and the lack of direct biological action on cartilage in vitro suggest, however, that GH itself does not have a direct action on the growth process at tissue level. The GH dependence of somatomedin is well documented and the somatomedins seem to play a key role in the homoeostatic mechanism regulating skeletal growth. Furthermore, a bioassay for somatomedin is more likely to be directly related to growth processes than an assay for $\mathrm{GH}$ based on antigenic properties. Human $\mathrm{GH}$ is now widely available for treatment but produces benefit only in patients with growth retardation associated with $\mathrm{GH}$ deficiency. The investigation of somatomedin activity in growth disorders is therefore of considerable interest.

The correlation we have shown between somatomedin activity and chronological age in normal children confirms the findings of Kogut et $a l^{21}$ and Van den Brande and Du Caju. ${ }^{22}$ When somatomedin is assessed in children with growth disturbance it is important to compare it with that of children of similar ages. Hall and Filippson ${ }^{23}$ found a negative correlation between chronological age and somatomedin activity in a large series of normal children and children with pituitary deficiency. Their patients with pituitary insufficiency were, however, older and had very low somatomedin activity. The lower levels of somatomedin in early childhood are of interest since growth velocity is then most rapid. This would imply that sensitivity to somatomedin is diminished with age. These findings are not at variance with the report of Hall and Filippson ${ }^{23}$ of a significant relation between growth velocity and somatomedin since their growth velocity measurements were taken at a constant maturational age based on the age of eruption of the permanent teeth. It seems reasonable that somatomedin activity should relate more closely to maturational than to chronological age, as our findings of a relation with bone age suggest.

In view of the GH dependence of somatomedin, reduced levels in GH-deficient children would be suspected and have been reported. ${ }^{21-23}$ In our series there was some overlap between values in short normal and hypopituitary children. This may be related to the fact that the control group was of less than average height. Hall and Filippson ${ }^{23}$ reported lower values for somatomedin activity in short children than in tall ones, although we could not show any relation between height and somatomedin activity in our series.

The increase of somatomedin activity in children with accelerated growth due to sexual precocity has not previously been reported. This finding would, however, be expected in view of the correlation of somatomedin activity with skeletal maturation and with growth velocity. The mechanism of this increase is not clear. Increased somatomedin production might be a secondary effect of the increased secretion of $\mathrm{GH}$ that occurs at puberty ${ }^{24}$ or a direct effect of sex hormone release.

We have confirmed previous reports ${ }^{7}$ that growth velocity is reduced when the glomerular filtration rate falls below $30 \mathrm{ml} /$ $\min / 1.73 \mathrm{~m}^{2}$. Although growth velocity fell in conjunction with a reduction in somatomedin activity in our patients with chronic renal insufficiency it is impossible to say whether the fall in somatomedin activity was the cause of poor growth, as it coincided with a reduction in the glomerular filtration rate.

The assay for somatomedin activity used the incorporation of radioactive sulphate into chick embryo cartilage. Sulphate concentrations may be raised in chronic renal insufficiency and may therefore influence the uptake of radiolabelled sulphate. ${ }^{18}$ Saenger $e t a l^{9}$ found that the somatomedin activity of uraemic sera with very high sulphate concentrations may be underestimated by about $30^{\circ}{ }_{0}$. They did not, however, state whether there was a linear correlation between somatomedin activity and serum sulphate concentrations. They made allowance for the increased inorganic sulphate concentrations in determining somatomedin activity. Audhya and Gibson, however, found no evidence for changed somatomedin activity in the presence of raised sulphate with serum dilutions less than $40^{\circ}{ }_{0} .^{25}$ In view of the conflicting evidence and because methods of determining inorganic sulphate are imprecise, we made no allowance for increased sulphate concentrations in our patients. In children with the severest depression of glomerular filtration rate correcting for the sulphate concentration by an increase in somatomedin activity of up to $30^{\circ}$ o would still have given subnormal results in children with reduced growth velocity.

Our results compare favourably with those of Ashton, ${ }^{26}$ who showed reduced somatomedin activity in patients with renal failure using a method incorporating labelled thymidine into cultured rabbit chondrocytes. The evidence suggests therefore that somatomedin activity is reduced in these children with low glomerular filtration rates and that the results are not an effect of an inhibitor on the bioassay system that increases in amount as glomerular filtration rate falls. Further work with more precise techniques for estimating inorganic sulphate and ensuring that other organic sulphates do not inhibit the assay system is required to confirm this finding.

Although the precise biological significance of the various GH-dependent growth factors, collectively termed somatomedin, remains to be elucidated, measurement of somatomedin activity adds a new dimension to the investigation of growth problems, which relates more closely to biological mechanisms than indices previously available.

We are grateful to Dr R H R White and Dr M Winterborn for allowing us to study children under their care and to Professor $W$ Butt, department of clinical endocrinology, Central Birmingham Health District, for performing growth hormone assays.

This work was supported by a Medical Research Council Project Grant No G973/805/C.

\section{References}

${ }^{1}$ Salmon, W D, jun, and Daughaday, W H, fournal of Clinical Investigation, 1956, 35, 733.

${ }^{2}$ Salmon, W D, jun, and Daughaday, W H, fournal of Laboratory and Clinical Medicine, 1957, 49, 825.

3 Daughaday, W H, et al, Nature, 1972, 236, 107

${ }^{4}$ Hall, K, Acta Endocrinologica, 1970, 63, 338.

5 Van den Brande, J L, and Du Caju, M U L, Acta Endocrinologica, 1974, 75, 233.

6 Uthne, K, Acta Endocrinologica, 1973, 73, Suppl p 175.

' Betts, P R, and Magrath, G, British Medical fournal, 1974, 2, 189.

McConaghey, P, and Sledge, C B, Nature, 1970, 225, 244.

9 Saenger, P, et al, Pediatric Research, 1974, 8, 163.

${ }^{10}$ Elders, M J, et al, American fournal of Diseases of Children, 1975, 129, 1393.

${ }^{11}$ Hartog, M, et al, British Medical fournal, 1964, 2, 1229.

12 Tanner, M J, Whitehouse, R H, and Takaishi, M, Archives of Disease in Childhood, 1966, 41, 454.

13 Greulich, W, and Pyle, S I, Radiographic Atlas of the Skeletal Development of the Hand and Wrist. Stanford, California, Stanford University Press, 1959

14 Glasgow, E F, Moncreiff, M W, and White, R H R, British Medical fournal, 1970, 2, 687.

15 Chantler, C, and Barratt, T M, Archives of Disease in Childhood, 1972, 47, 613.

${ }_{16}$ Grant, D B, et al, Archives of Disease in Childhood, 1973, 48, 596.

17 Borth, R, Acta Endocrinologica, 1960, 35, 454.

18 Wiedermann, E, personal communication, 1976.

19 Roth, J, et al, Metabolism, 1963, 12, 577.

${ }^{20}$ Glick, S M, and Goldsmith, S, in International Symposium on Growth Hormone, ed A Pecile and E Muller, p 84. Amsterdam, Excerpta Medica, 1968.

${ }^{21}$ Kogut, M, Kaplan, S A, and Schimizu, C S N, fournal of Pediatrics, 1963, 31, 538 .

${ }^{22}$ Van den Brande, $\mathrm{J} \mathrm{L}$, and Du Caju, M U L, in Advances in Human Growth Hormone Research, ed S Raiti, p 98. Washington, DC, US Department of Health, Education and Welfare, 1974.

${ }^{23}$ Hall, K, and Filippson, R, Acta Endocrinologica, 1975, 78, 239.

24 Frasier, S D, Hilburn, J M, and Smith, F G, Fournal of Pediatrics, 1970, 77, 465.

${ }^{25}$ Audhya, T K, and Gibson, R D, Endocrinology, 1974, 95, 1614.

${ }^{26}$ Ashton, K, personal communication, 1976.

(Accepted 6 Fanuary 1977) 